\title{
YIELD STABILITY AND FARMER PREFERENCE OF COWPEA (VIGNA UNGUICULATA) LINES IN SEMI-ARID EASTERN KENYA
}

\author{
Rose Wangari Kuruma ${ }^{1}$, Patrick Sheunda ${ }^{2}$ and Charles Muriuki \\ Kahwaga $^{1}$ \\ 1 Kenya Agricultural and Livestock Research Organization (KALRO) \\ 2 International Crops Research Institute for the Semi-Arid Tropics (ICRISAT)
}

\begin{abstract}
Stability in yields of agronomically acceptable cultivars is generally regarded as the ultimate goal in cowpea improvement. Nine advanced cowpea lines and 3 local checks were evaluated for grain yield in eastern Kenya with the aim of identifying stable genotypes and integrating farmer preferences. The study was conducted in 3 locations over 2 years under a randomized complete block design with 3 replications. Stability was estimated using additive main effects and multiplicative interaction (AMMI) and genotype by environment (GGE) models. There was variation among genotypes, locations and their interactions for grain yield. Genotype G5, G9 and G2 were found to be stable and high yielding. Environments Kit16 and Kit15 were considered as the most suitable for selecting superior genotypes for adaptability and stability. Farmers' criteria for selecting genotypes included early maturing, pod length, disease tolerant and high yielding varieties. Cowpea performance for grain yield was greatly influenced by inherent genotypic factors, environment and their interaction effects.
\end{abstract}

KEY WORDS: COWPEA, ENVIRONMENT, GENOTYPE BY ENVIRONMENT INTERACTION, STABILITY, GRAIN YIELD

\section{Introduction}

Cowpea (Vigna unguiculata) is the second most important legume crop after common beans in Kenya, and is cultivated predominately in warm climates in the semi-arid tropics and subtropics (Kariuki, 2015; Sani et al., 2014). Being a drought tolerant and warm weather crop, cowpea is well adapted to the drier regions of the tropics where other food legumes do not perform well (Agbicodo et al., 2009). This crop accounts for roughly $\mathrm{r} \%$ of Kenya's pulse production with $90 \%$ of the total production occurring and consumed in semi-arid (SAL) region of Eastern Kenya, mainly in Kitui, Machakos, Makueni, Embu, and Tharaka-Nithi counties (USAID, 2010). The SAL region is generally characterized by low, erratic and poorly distributed rainfall ranging from $100-900 \mathrm{~mm} / \mathrm{yearly}$, resulting in low yields (Miriti et al., 2012).

Cowpea grain is rich in protein with some varieties having up to $30 \%$ protein content in addition to micronutrients such as iron and zinc which are necessary for healthy living (Boukar et al., 20II). From its production, rural families derive food, animal feed and 
income through the sale of the grain and fresh leaves (IITA, 2009). Further, the bacteria in its root nodules contribute to soil fertility by fixing atmospheric nitrogen in the soil (Tijjani et al., 20I5) thereby reducing the need for nitrogen fertilizer and so costs.

Despite its importance, cowpea production in Kenya remains at a low level declining from about 173 , 000 MT in 2015 to about 146,000 MT in 2017 even though there was an increase in area planted in the year 2017 with 260,000 hectare (ha) compared to 238,000 in the year 2015 (FAOSTAT, 2018). Further, in the farmers' fields cowpea cultivation is poor with less than $0.3 \mathrm{tha}^{-\mathrm{I}}$, compared to potential yield of more than $\mathrm{I} .5 \mathrm{t}$ ha $\mathrm{a}^{-\mathrm{I}}$ to $2.5 \mathrm{t}$ $\mathrm{ha}^{-1}$ of grain reported in research stations (Ajeibe et al., 2010). The low yield production is attributed to climate related issues including, severe attack of pest complexes, diseases, increases in temperature, frequency of droughts, low soil fertility and the use of inappropriate cultivars (Chepkoech et al., 20I8) among other limiting factors. In addition, Hutchinson et al. (2017) argue that, cowpea farmers have a high preference for local land races compared to improved varieties due to their palatability and adaptability despite their low yields attributes.

In the past decades, plant breeders developed improved varieties under controlled experimental conditions in favorable environments with no consideration of farmers' preferences and needs (Ceccarelli et al., 20I2; FAO 20I4). This scenario resulted in low adoption of developed improved varieties (Luna et al., 2012). A few studies have shown the role of varietal traits on the adoption of improved varieties. For instance, Salifou et al. (2017) reported that farmers adopt improved varieties that combine traits of their choice with features that correspond to their local conditions. Similarly, Saidou et al. (20II) inferred that farmers preferred early maturing varieties, with good grain size, seed coat color and high yielding potential, while Asrat et al. (2009) deduced that farmers preferred crop varieties with strong adaptability and yield stability parameters.

In Kenya there is no information on yield stability based on genotype by environment interaction (GEI) effects coupled with farmers' perceptions and needs. Stability in yields of agronomically acceptable cultivars is generally regarded as the ultimate goal in cowpea improvement (Afyeman et al., 20I4). However, yield is a complex quantitative trait and such traits are often controlled by many genes influenced by prevailing environmental effects with each gene having a small effect (Quarrie et al., 2006). The effects of the genotype by environment interaction (GEI) hampers breeding by inducing variations in genotype performance in different environments thereby jeopardizing selection (Cargnin et al., 2006). One strategy for reducing GEI effects involves analyzing for adaptation and stability parameters to identify genotypes with predictable performance which are responsive to environmental variations in specific or wide conditions (Farshadfar et al., 20II; Cruz et al., 2012).

Studies by Vita et al. (2010) and Carvalho et al. (2016) depicted that genotype stability and adaptability to environment can be qualitatively assessed using graphical representation that distributes the genotypes according to their principal component (PC) values. Some of the methodologies used include AMMI (additive main effects and multiplicative interaction) bi-plots model (DDmulira et al., 2015; Santos et al., 2015) and GGE (genotype plus 
genotype by environment) bi-plots (Santos et al., 20I6). The models combine the analysis of variance of the genotype by environment main effects, with the principal components analysis (PCA) of the G x E interactions, and simultaneously identifies genotypes with high grain yield and stability for a wide range of environments (Mehari et al., 2015). For instance, the AMMI model was effective in distinguishing genotypes that performed in mega-environments and identified varieties that had stable performance in Vigna radiata (Singh et al., 2014). Similarly, Funga et al (2017) and Rashidi et al. (2013) used the AMMI method to analyze stability and adaptation of chickpea genotypes over eight environments in major chickpea producing areas of Ethiopia and Iran, respectively. The GGE model of analysis has helped to explain GEI in diverse agro-ecologies for cowpeas (Santos et al., 20I6), chickpea (Tilahuni et al., 2015; Kanouni et al., 2015); lentil (Idrissi et al., 20I9) and pigeon pea (Thanki et al., 20Io). The model was used to study varietal stability in mega environments assessment (Kumar et al., 20I2). In order to identify the most stable and high yielding genotypes it is imperative to assess the genotypes in multi-environmental trials (Raboanatahiry et al., 2018).

Hence, investigation of the magnitude of the genotype-by-environment interaction as well as the genotypes adaptability and stability is a useful step in developing breeding varieties that will perform to their full potential in the target environments (Muranaka et al., 20I6). Therefore, this study was undertaken to evaluate advanced cowpea breeding lines for grain yield stability coupled with smallholder farmers' perceptions and needs in the semi-arid regions of Kenya. Indeed, cultivars with high yielding potential and good adaptability and stability could be recommended for release in different environments in Kenyan.

\section{Materials and Methods}

\section{Study Sites}

This study was carried out at three experimental stations of the Kenya agricultural Livestock and research organization (KALRO) in Kiboko, Kitui and Kambi Mawe during the cropping seasons of 2015 short rains (SR) and 2016 long rains (LR) representing six testing environments (location by year). The crop was grown under rainfed conditions in Kitui and Kambi mawe testing sites while Kiboko was supplemented with irrigation due to moisture stress. The locations fall under semi-arid region of eastern Kenya (Jaetzold et al., 2006) which experiences a bimodal rainfall pattern with long rains occurring from March - May and short rains from October - December. The rains are usually low, erratic and poorly distributed within the cropping season.

\begin{tabular}{|c|c|c|c|c|c|c|c|c|}
\hline \multirow[t]{2}{*}{ Location } & \multirow[t]{2}{*}{ Years } & \multirow[t]{2}{*}{ Latitude } & \multirow[t]{2}{*}{ Longitude } & \multirow{2}{*}{$\begin{array}{l}\text { Altitude } \\
\text { (m. asl) }\end{array}$} & \multicolumn{2}{|c|}{ Temp ( $\left.{ }^{\circ} \mathrm{C}\right)$} & \multirow{2}{*}{$\begin{array}{l}\text { Rainfall } \\
\text { (mm) }\end{array}$} & \multirow[t]{2}{*}{ Soil type } \\
\hline & & & & & Min & Max & & \\
\hline Kiboko & 2015SR & $02^{\circ} 21^{\prime} \mathrm{S}$ & $37^{\circ} 72^{\prime} \mathrm{S}$ & 975 & 18 & 30 & $\approx 200$ & Sandy clay \\
\hline Kitui & 2015SR & $01^{\circ} 37^{\prime} \mathrm{S}$ & $38^{\circ} 01^{\prime} \mathrm{S}$ & 1155 & 15 & 28 & $\approx 500$ & $\begin{array}{l}\text { Reddish } \\
\text { Sandy loam }\end{array}$ \\
\hline
\end{tabular}




\begin{tabular}{l|l|l|l|l|l|l|l|l}
\hline $\begin{array}{l}\text { Kambi } \\
\text { Mawe }\end{array}$ & $2015 \mathrm{SR}$ & $01^{\circ} 37^{\prime} \mathrm{S}$ & $37^{\circ} 40^{\prime} \mathrm{S}$ & 1125 & 18 & 29 & $\approx 500$ & Sandy clay \\
\hline Kiboko & $2016 \mathrm{LR}$ & $02^{\circ} 21^{\prime} \mathrm{S}$ & $37^{\circ} 72^{\prime} \mathrm{S}$ & 975 & 18 & 30 & $\approx 200$ & Sandy clay \\
\hline Kitui & $2016 \mathrm{LR}$ & $01^{\circ} 37^{\prime} \mathrm{S}$ & $38^{\circ} 01^{\prime} \mathrm{S}$ & 1155 & 15 & 28 & $\approx 300$ & $\begin{array}{l}\text { Reddish } \\
\text { Sandy loam }\end{array}$ \\
\hline $\begin{array}{l}\text { Kambi } \\
\text { Mawe }\end{array}$ & $2016 \mathrm{LR}$ & $01^{\circ} 37^{\prime} \mathrm{S}$ & $37^{\circ} 40^{\prime} \mathrm{S}$ & 1125 & 15 & 29 & $\approx 300$ & Sandy clay \\
\hline
\end{tabular}

* LR= Long rain and SR= Short Rain: Cropping seasons

Table 1: Description of the cowpea study sites in Eastern region

\section{Plant materials and Experimental design}

Nine cowpea advanced breeding lines, along with 3 improved check varieties were laid out in a randomized complete block design with three replications. Each breeding line was planted in a 4 row plot of $4 \mathrm{~m}$ length with inter-row spacing of $0.6 \mathrm{~m}$ and intra-row spacing of $0.2 \mathrm{~m}$. Two seeds were planted per hill and later thinned to one plant per hill two weeks after emergence. Foliar and pod pests were controlled using Imidacloprid + Betacyflutherine and Flubendiamide $480 \mathrm{~g} / \mathrm{L}$ ) whereas fungal and bacterial disease were controlled using copper-oxychloride. The plots were maintained weed free by hand hoeing.

Yield data was collected in two middle rows (net plots) according to International Board for Plant Genetic Resources (IBPGR) cowpea descriptors and extrapolated to grain yield per hectare $\left(\mathrm{t} \mathrm{ha} \mathrm{h}^{-1}\right)$.

\begin{tabular}{|c|c|c|}
\hline Code & Breeding line & Pedigree \\
\hline G1 & 1003 & Kvu27-1 (Local check) \\
\hline G2 & $1005 / 1002 / 1 / 1 / 1$ & IT99K-573-1-1XM66/1/1/1 \\
\hline G3 & 1004 & K80 (Local check) \\
\hline G4 & $1005 / 1004 / 5$ & IT99K-573-1-1 XK80 \\
\hline G5 & $1003 / 1001 / 3$ & Kvu27-1 ×B301 \\
\hline G6 & $1005 / 1004 / 1$ & IT99K-573-1-1 x M66/1 \\
\hline G7 & $1002 / 1005 / 3$ & M66 x IT99K-573-1-1/3 \\
\hline G8 & $1004 / 1001 / 3$ & $\mathrm{~K} 80 \times \mathrm{B} 301 / 3$ \\
\hline G9 & $1005 / 1003 / 3$ & IT99K-573-1-1 x Kvu27-1/3 \\
\hline G10 & $1005 / 1002 / 1$ & IT99K-573-1-1 x M66/1 \\
\hline G11 & 1001 (check) & B301 (IITA Check) \\
\hline G12 & $1005 / 1002 / 2 / 1 / 1$ & IT99K-573-1-1 x M66/2/1/1 \\
\hline
\end{tabular}

Table 2: Cowpea advanced breeding lines tested during the 2015SR and 2016LR season

Data was subjected to analysis of variance (ANOVA) using the Genstat software (Genstat, 20I2) statistical programme to determine significance of main effects consisting of year $(\mathrm{Y})$, Location (L) and Genotypes and their interactions (GEI). Grain yield ( $\mathrm{t} \mathrm{ha}^{-1}$ ) per en- 
vironment was analyzed separately to observe the mean performance. The ANOVA model used was:

$X_{i j k}=\mu+G_{i}+L_{j}+Y_{k}+(G L)_{i k}+(L Y)_{j k}+(G L Y)_{i j k}$

Where, $X_{i j k}$ is the mean yield over r replications of the $i^{\text {th }}$ genotype in the $j^{\text {th }}$ location in year $\mathrm{k}$ with the right side of the equation giving grand mean yield $\mu$ and respective main and interaction effects of the genotypes $(\mathrm{G})$, locations $(\mathrm{L})$ and years $(\mathrm{Y})$. The magnitude of variance components was computed as the percentage of total variation to determine the contribution of the main and interaction effects in total variations of yield. Combined mean performance of genotypes for 3 locations and 2 years, treated as six (6) environments, was computed to generate a genotype by environment two-way table data for the bi-plot analysis

\section{Additive main effect and multiplicative interaction analysis}

The AMMI model was applied with additive main effect of the I2 cowpea genotypes (G) and six testing environments ( 3 growing sites and 2 seasons) and multiplicative term for GEI. The AMMI model first fits additive effects for genotypes and environments by ANOVA procedure and then fits multiplicative effects for $\mathrm{G}$ x E (genotype environment) by principal component analysis (PCA). The AMMI model according to Farshadfar et al., (20II) is represented as:

$$
\gamma_{i j}=\mu+g_{i}+e_{j}+\sum_{k=1}^{N} \lambda_{k} \alpha_{i k} \gamma_{j k}+\varepsilon_{i j}
$$

Where: $\gamma_{i j}$ is yield of the $i^{\text {th }}$ genotype in the $j^{\text {th }}$ environment, $\mu$ is the overall mean, $g_{i}$ is the $i^{\text {th }}$ genotype mean deviation, $e_{\mathrm{j}}$ is the $\mathrm{j}^{\text {th }}$ environment mean deviation, $\lambda_{\kappa}$ is the square root of the eigen value of PCA axis $\mathrm{k}, \alpha_{\mathrm{ik}}$ and $\gamma_{\mathrm{jk}}$ are the principal components scores for PCA axis $k$ of the $i^{\text {th }}$ genotype and $j^{\text {th }}$ environment, respectively, and $\varepsilon_{i j}$ is the residual.

The AMMI bi-plot graphic interpretation was based on the variation caused by the main additive effects of genotype and environment and the multiplicative effect of $\mathrm{G} \times \mathrm{E}$ interaction. The abscissa represents the main effects and the ordinate is the first interaction axis (IPCAI). The lower the IPCA value (absolute values), the lower its contribution to the $\mathrm{G} \times \mathrm{E}$ interaction, and therefore, the more stable the genotype. Desirable genotype is a high yielder with IPCAI scores close to zero while, undesirable genotype has low stability associated with low yield (Ferreira 2006).

\section{Genotype plus genotype by environment Analysis}

The Genotype plus genotype by environment (GGE) bi-plots were constructed from the firsts two principal components (PCI \& PC2) derived by subjecting the environment centered yield data which contains $\mathrm{G}$ and GE to singular valued composition (Yan and Rajcan, 2002). The first principal component is highly correlated with the main effect of the genotype while the second component represents the part of the yield that results from $\mathrm{G}$ x E interaction (Yan et al 2000 ;Yan, 20II). The GGE Bi-plot model maintains the terms G 
and $\mathrm{G} \mathrm{XE}$ together in two multiplicative terms which is shown in the following equation: $Y_{i j}-\overline{\mathrm{y}}_{j}=\lambda_{1} \xi_{i 1} \eta_{j 1}+\lambda_{2} \xi_{i 2} \eta_{j 2}+\varepsilon_{i j}$

Where $Y_{i j}$ is the average yield of genotype $i$ in environment $j ; \bar{y}_{j}$ is the average yield over all genotypes in environment $j$; and $\lambda_{1} \xi_{i 1} \eta_{j 1}$ and $\lambda_{2} \xi_{i 2} \eta_{j 2}$ are the first principal component (PCI) and the second principal component (PC2); $\lambda_{1}$ and $\lambda_{2}$ are the singular values for the first and second principal components $\mathrm{PC}_{\mathrm{I}}$ and $\mathrm{PC}_{2}$, respectively, for $\xi_{i 1}$ and $\xi_{i 2}$ are the PCI and PC2 scores respectively; for genotype $i ; \eta_{j 1}$ and $\eta_{j 2}$ are the PCI and PC2 scores respectively, for environment $j$; and $\varepsilon_{i j}$ is the residual of the model associated with genotype $i$ in the environment $j$.

The genotype plus genotype and environmental interaction (GGE) bi-plot analysis (Yan, 200I) was used to generate all bi-plot graphs showing (i) ranking of genotypes on basis of mean yield and stability and (ii) which genotype won where pattern (Yan et al., 2007)

\section{Farmers' perceptions and preferences}

At the full pod development stage, the research team invited farmer groups who are actively engaged in cowpea production to participate in a variety selection exercise to identify and select farmer preferred genotypes. Stakeholders from the ministry of agriculture and seed merchants were also invited to participate in the exercise. Stakes were placed with a bag attached in front of each plot of the trial to serve as a ballot box for casting the vote. Farmers were allowed to walk through the trial to familiarize themselves with varieties planted before voting. The male and female farmer-participants were provided with different colors of ballots to signify, positive or negative variety of choice by gender. Each farmer was presented with 5 ballots for casting the best and 5 ballots for worst cultivars. After the exercise the votes were tallied by the researchers and a few farmers and the results were presented to the whole group for discussion. Through probing questions guided by a single page questionnaire farmers were requested to outline the criteria of how and why they chose the best varieties and the reasons why they disliked a variety. Each criterion was scored on a scale of $\mathrm{I}$ to 5 ( $\mathrm{I}=$ Excellent; 2 = Very Good; 3 = Good; $4=$ Fair; 5 = Worst) for each variety. Preference score (PS) for each cowpea line was generated by calculating data on positive votes cast minus the negative votes divided by the total number of votes that were cast by the farmers (Paris et al, 20II)

Preference scores (PS) for each variety is calculated as:

PS $=\frac{\text { Number of positive votes }- \text { negative votes }}{\text { Total number of positive and negaive votes }}$

\section{Results}

Combined Analysis of Variance and Cowpea Mean Grain Yield

Results of the combined analysis of variance for grain yield are presented in Table 3 which gives an overall picture of the relative magnitude of genotype $(\mathrm{G})$, year $(\mathrm{Y})$, location $(\mathrm{L})$ and their interactions variance terms. Mean square (MS) associated with genotype (G), year $(\mathrm{Y})$ and location $(\mathrm{L})$ main effects as well as interactions effects of genotype-by-loca- 
tion (GL), genotype-by-year-by location (GYL) were highly significant ( $p<0.00 \mathrm{I}$ ). The partitioning of interactions variance components effects $\mathrm{L} \times \mathrm{Y}, \mathrm{G} \times \mathrm{L}$ and $\mathrm{G} \times \mathrm{Y} \times \mathrm{L}$ explained 10\%, I0\% and 8\%, total sum of squares (TSS), respectively (Table 3). In contrast, total grain yield variation due to location, year and genotype explained $24 \%$, $15 \%$ and $7 \%$, respectively.

The mean grain yield of genotypes differed from year to year ranging between 2.49 tha $^{-1}$ to $\mathrm{I} .49 \mathrm{t} \mathrm{ha}^{-1}$ in $2015 \mathrm{SR}$ cropping season while in 20I6LR the performance ranged between $\mathrm{I} .62 \mathrm{t} \mathrm{ha}^{-1}$ to $0.90 \mathrm{t} \mathrm{ha}^{-1}$ (Table 4). Overall the mean grain yield value over environments indicated that genotype (G6) $1005 / 1004 / \mathrm{I}$ had the highest mean of $\mathrm{I} .82 \mathrm{t} \mathrm{ha-{ } ^ { \mathrm { I } }}$ with a margin of $35 \%$ advantage higher than the lowest grain yield genotype (GIO) I005/I002/I and with over $5.5 \%$ of the highest yielding check variety.

\begin{tabular}{l|l|l|l|l}
\hline Source of variation & DF & SS & MS & \%TSS \\
\hline Year (Y) & 1 & 17.62 & $17.61^{* * *}$ & 15 \\
\hline Location (L) & 2 & 29.27 & $14.63^{* * *}$ & 24 \\
\hline LxY/Environment & 2 & 11.61 & $5.80^{* * *}$ & 10 \\
\hline Genotype (G) & 11 & 8.05 & $0.73^{* * *}$ & 7 \\
\hline Genotype x Year (GY) & 11 & 5.51 & $0.5^{\text {ns }}$ & 5 \\
\hline Genotype x Location (GL) & 22 & 12.64 & $0.57^{* * *}$ & 10 \\
\hline Genotype x Year x Location (GYL) & 22 & 9.59 & $0.44^{* * *}$ & 8 \\
\hline Error & 132 & 21.66 & 0.16 & \\
\hline
\end{tabular}

*** Significance at $p \leq 0.001 ;$ ns: non-significant $p>0.05$

Table 3: Combined analysis of variance of grain yield of 12 cowpea genotypes tested in 3 locations in 2015 and 2016

\begin{tabular}{|c|c|c|c|c|c|c|c|c|c|}
\hline 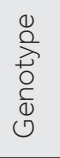 & 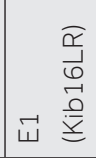 & 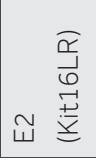 & 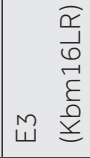 & 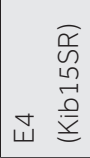 & 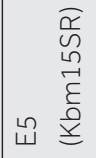 & 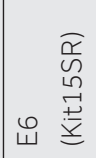 & 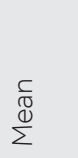 & $\begin{array}{l}n \\
\stackrel{n}{\sim}\end{array}$ & $\begin{array}{l}0 \\
\text { - } \\
\text { N }\end{array}$ \\
\hline G1 & 1.04 & 1.51 & 0.30 & 1.80 & 1.16 & 1.90 & 1.28 & 1.6 & 0.97 \\
\hline G2 & 2.16 & 1.65 & 0.42 & 1.93 & 1.54 & 2.03 & 1.62 & 1.81 & 1.43 \\
\hline G3 & 2.52 & 1.63 & 0.44 & 1.88 & 1.87 & 2.03 & 1.73 & 1.88 & 1.58 \\
\hline G4 & 1.82 & 1.71 & 0.67 & 1.93 & 2.34 & 2.18 & 1.77 & 2.2 & 1.35 \\
\hline G5 & 1.76 & 1.79 & 0.58 & 2.08 & 1.58 & 2.18 & 1.66 & 1.98 & 1.34 \\
\hline G6 & 1.44 & 1.74 & 0.80 & 1.94 & 2.72 & 2.27 & 1.82 & 2.49 & 1.14 \\
\hline G7 & \begin{tabular}{|l|}
1.77 \\
\end{tabular} & 1.37 & 0.22 & 1.62 & 1.58 & 1.79 & 1.39 & 1.73 & 1.05 \\
\hline G8 & 2.89 & 1.50 & 0.38 & 1.72 & 2.22 & 1.94 & 1.77 & 1.92 & 1.62 \\
\hline
\end{tabular}




\begin{tabular}{l|l|l|l|l|l|l|l|l|l}
\hline G9 & 1.93 & 1.68 & 0.45 & 1.97 & 1.46 & 2.05 & 1.59 & 1.88 & 1.29 \\
\hline G10 & 0.85 & 1.64 & 0.35 & 1.97 & 0.77 & 1.98 & 1.26 & 1.63 & 0.89 \\
\hline G11 & 0.88 & 1.40 & 0.37 & 1.62 & 1.89 & 1.88 & 1.34 & 1.49 & 1.19 \\
\hline G12 & 2.38 & 1.85 & 0.40 & 2.22 & 0.68 & 2.11 & 1.61 & 1.65 & 1.57 \\
\hline mean & 1.78 & 1.62 & 0.45 & 1.89 & 1.65 & 2.03 & 1.57 & 1.86 & 1.29 \\
\hline
\end{tabular}

Table 4: Mean grain yield of cowpea genotypes tested in 6 environments (LY) over two years

\section{AMMI analysis of variance for $G, E$ and $G E I$}

The AMMI analysis of cowpea grain yield in six testing environments showed that both IPCAI and IPCA2 were highly significant ( $p<0.00$ ) (Table 5). IPCAI explained 40.68\% of genotype by environment (GE) interaction sum of squares, whereas IPCA2 explained $36.57 \%$. Significant effects ( $\mathrm{p}<0.00 \mathrm{I}$ ) were detected for genotype, environments and the G, GE interactions (Table 5). The environment effect was responsible for greatest proportion of variation ( $62 \%)$, followed by effects of GE interactions and genotypes.

\begin{tabular}{l|l|l|r|l}
\hline Source of variation & DF & SS & MS & \%TSS \\
\hline Treatments & 71 & 94.28 & $1.33^{* * *}$ & \\
Genotypes & 11 & 8.05 & $0.73^{* *}$ & 8.5 \\
Environments & 5 & 58.5 & $11.70^{* * *}$ & 62.0 \\
Block & 12 & 5 & $0.42^{* *}$ & \\
Interactions & 55 & 27.73 & $0.50^{* * *}$ & 29.4 \\
IPCA & 15 & 11.28 & $0.75^{* * *}$ & 40.68 \\
IPCA & 13 & 10.14 & $0.78^{* * *}$ & 36.57 \\
Error/residue & 132 & 21.66 & 0.16 & \\
\hline
\end{tabular}

Table 5: Additive Main Effect and Multiplicative Interaction analysis for yield of 12 cowpea genotypes

Stability and adaptability analysis

Bi-plot graphs of the AMMI (IPCAI \& IPCA2 versus additive effects from genotypes and environments) are shown in Figure I. The characterization of each promising genotype based on mean grain yield and contribution to GEI by mean of IPCAI (Figure I) indicates that genotype G6 (1005/1004/I) and G4 (1005/1004/5) specifically adapted to environments Kbmi5 and KitI5 (Figure I). In regard to their contribution to GEI (i.e. stability) the IPCAI score, genotypes $\mathrm{G}_{4}$ was most stable in KitI5 while genotype G6 in environment Kbmi5 amongst the high yielding environments. On the other hand, genotypes $\mathrm{G}_{5}$ (1005/1003/3), G9 (1005/1003/3) and G2 (1005/1002/I/I/I) were most stable and broadly adapted, as indicated by values near origin of the IPCAI and had smaller contribution to genotype by environmental interactions (GEI) as indicated IPCA2 scores. Genotype G7 was a relatively stable but had a grain yield lower than the grand mean. 

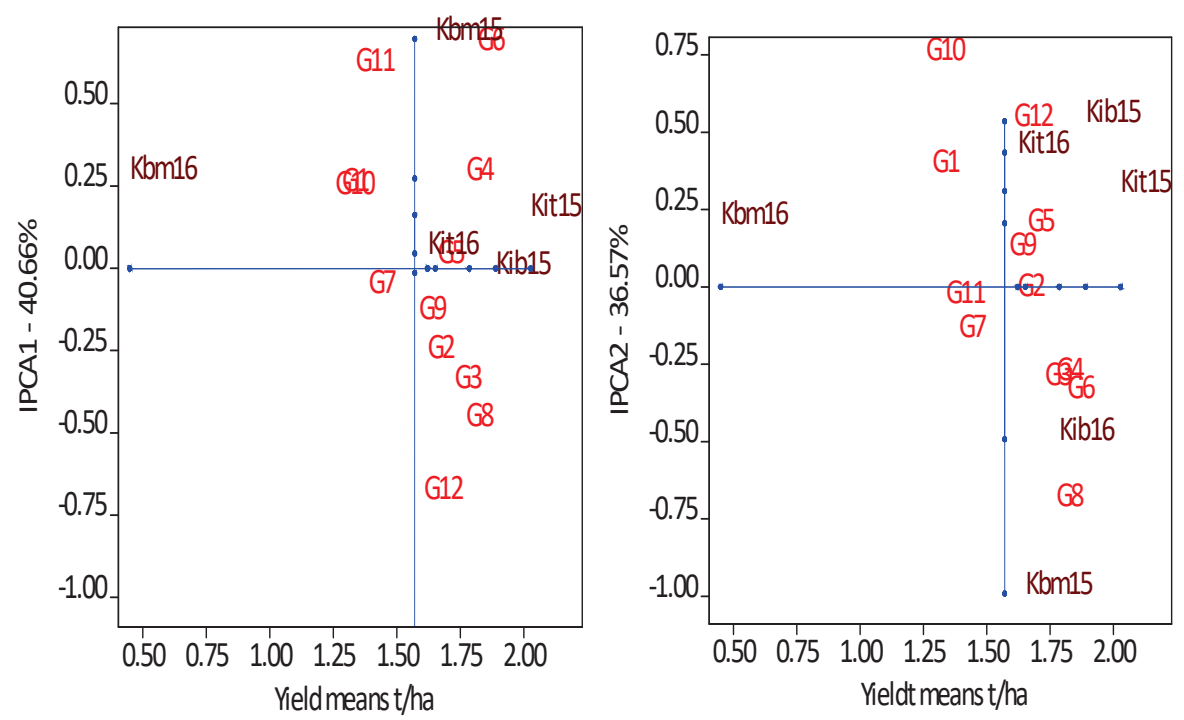

Figure 1: AMMI Bi-plot cowpea genotype and environment of IPCA1 \&2 versus grain yield (t ha- 1 ) of 12 genotypes in 6 environments.

The lowest yielding environment KbmI6 (Kambi mawe 2016 LR) recorded positive IPCA I \& 2 (Fig I) scores and was located at some distance from all genotypes showing that it interacted poorly with genotypes. Environment Kitr6 (Kitui 20I6LR) elicited low interactions with most of the genotypes as it was located near point of origin (low IPCA scores).

\section{Genotype and Genotype by Environment yield performance}

The Genotype and Genotype by Environment (GGE) bi-plots describes the genotypic main effects $(G)$ and genotype-by-environment interactions (GE) effect. In this study, the results of GGE bi-plots showed that the first two principal components (PCI and $\mathrm{PC}_{2}$ ) accounted for $75.2 \%$ total variation caused by G + GEI. PCI accounted for $44.37 \%$ while PC2 $32.82 \%$ of the total variation (Figure 2[i \& ii]). Figure 2(i) shows mean yield and stability performance of the tested genotypes based on the average tester coordinate (ATC) axis. The stability and mean yield performance of genotype is measured by the projections of their markers on the ATC axis. Short projections to the axis indicate genotypes with high stability while long vectors elicit unstable genotypes. Genotypes $\mathrm{G}_{5}, \mathrm{G}_{7}$ and $\mathrm{G}_{3}$ had very short vectors in relation to the ATC axis indicating high stability while Gio and GI depicted least stability with poor performance (Figure 2[i]). Genotype G5, $\mathrm{G}_{2}, \mathrm{G} 9$, and $\mathrm{G}_{3}$ exhibited the highest stability and achieved a grain yield above the overall mean. However, genotypes G6, G4, G8 and GI2 though high yielding were unstable genotypes across environments as explained by long projection vectors on the ATC axis. 

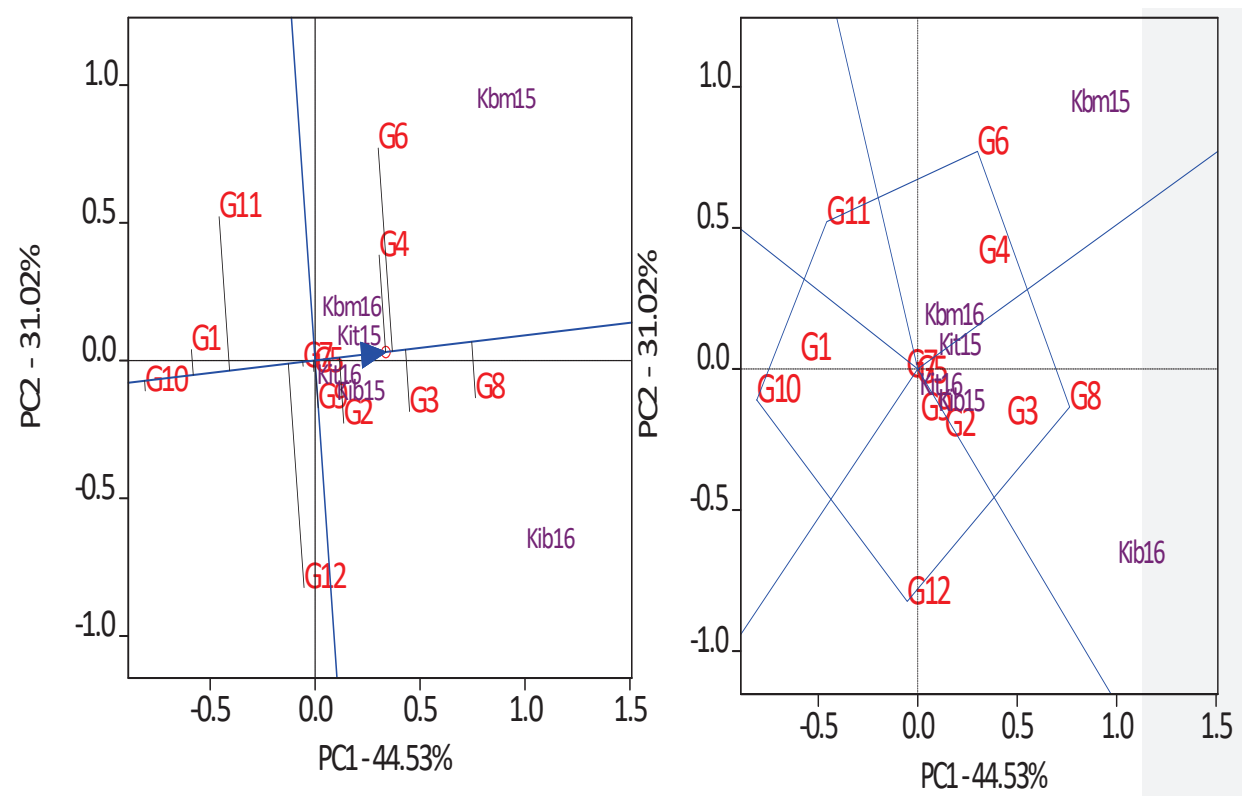

Figure 2: AEC results of GGE bi-plot for (i) Yield stability (ii) Which-won-where. Environments Kib16 reps. Kiboko 2016 Long Rain, Kib15 Kiboko 2015 Short Rain, Kbm16 for Kambi Mawe 2016 Long Rain, Kbm15 = Kambi Mawe 2015 Short Rain,

Figure 2(ii) shows the vertices of the polygon with genotype markers located farthest away from the bi-plot origin, such that all the genotypes are contained within the polygon. The test environments fell into three cowpea growing mega-environments out of five sectors outlined in polygon view. The first grouping of mega-environments was represented by Kbmi6 and Kbmi5, while the second mega-environment by Kibr6 and KitI5SR and third with Kibi5 and Kitr6.

Genotype $\mathrm{G} 6$ and $\mathrm{G}_{4}$ was associated with mega-environment groups KbmI5 and Kbmi6 with G6 being at the vertex. The second mega environments Kibr6 and KitI5 contained genotype $\mathrm{G} 8$ as the most responsive genotype and $\mathrm{G}_{3}$, while the third mega-environmental group was Kibi5 and Kitr6 with $\mathrm{G}_{5}, \mathrm{G}_{9}$ and $\mathrm{G}_{2}$, with winning genotype (GI2) I005/I002/2/I/I at the vertex. Two vertex genotypes GII (IOOI) and GIo (I005/I002/I) without any environment were the poorest genotypes in most of the environments with the lowest mean yield.

\section{Farmer preferences in selection of cowpea genotypes}

Figure 3 shows the farmer preference score (PS) and perceptions of best and least preferred genotypes by male and female participants (Fig 3). Both genders agreed on their preferences for the best performing genotypes tested in cowpea trials. For example, genotypes $\mathrm{G}_{7}$, G8, and $\mathrm{G}_{5}$ were preferred by both male and female farmers (Fig. 3). Similarly, comparing the farmers' results and yield data calculated by the researcher in Table 
4, female farmers chose genotypes $\mathrm{G}_{4}, \mathrm{G} 8, \mathrm{G}_{7}$ and $\mathrm{G} 6$ which were superior genotypes in yield attributes whereas male participants selected genotypes $\mathrm{G}_{5}, \mathrm{G}_{7}$ and $\mathrm{G}_{3}$ (Fig 3).

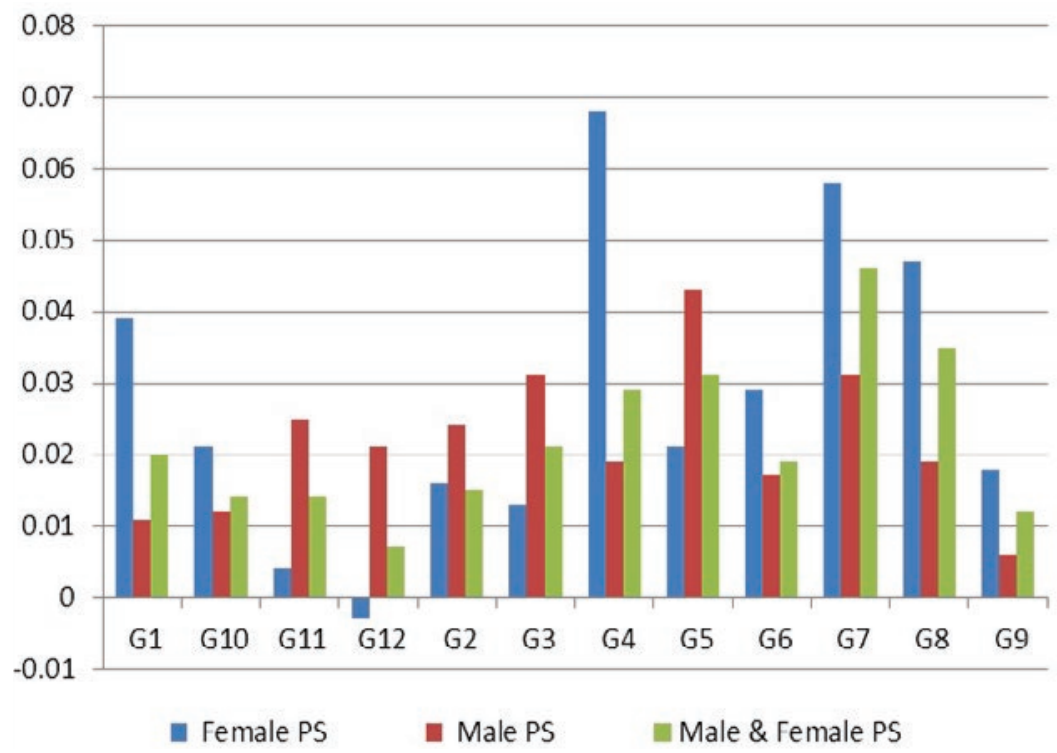

Figure 3: Preference scores of cowpea genotypes preferred by male and female farmers and combined perceptions in eastern Kenya

Figure 4, shows criteria of how both male and female farmers selected best and preferred cowpea genotypes for growing in their own environments. Early maturing long pods, high yielding and disease resistant varieties were the criteria adopted by farmers. Women selected genotypes with large grain with good seed color as significant criteria. 


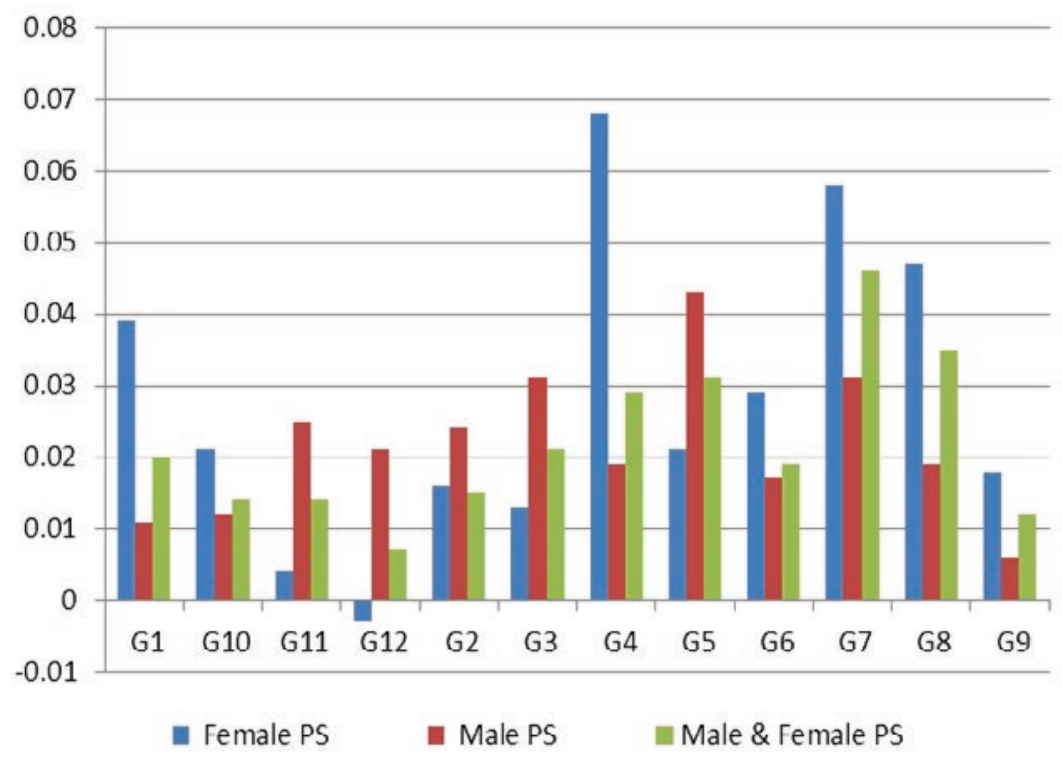

Figure 4: Farmers' criteria in selecting preferred cowpea genotypes

\section{Discussion}

The presence of significant genotype $(\mathrm{G})$, years (Y, location (L) main effects and genotype by environment (GE) in ANOVA suggests differential responses of the genotypes and the need to identify high yielding and stable genotypes across test environments. Sousa et al., (2018) found similar results for these three sources of variation in cowpea genotypes. The location (L) variation (24\%) indicated that the tested locations in this current study were diverse with the largest differences among locations effects causing the most variation in genotype performance. The magnitude of genotype by location interactions (I0\%) for yield per hectare ( $\mathrm{t} \mathrm{ha} \mathrm{a}^{-1}$ ) was larger than that of genotype $(7 \%)$. The $\mathrm{G} \times \mathrm{L}$ interactions effects demonstrated that genotypes responded differently to different locations, confirming the importance of testing cowpea genotypes at multi-locations in Eastern Kenya. Oladosu et al., (2017) reported differences in responses of genotype across locations in different seasons. In addition variation due to locations and years (LY/ environment) and genotype by environment interaction (GEI) in relation to genotype effect suggested that there was possibility of existence of mega environments with different genotypes.

Differences in grain yield $\left(\mathrm{tha}^{-1}\right)$ means were observed in genotypes evaluated in different environments. The highest grain yield was detected by genotype 1005 x 1004/I (G6) which had a yield advantage of $35 \%$ compared to the worst performing genotype $1005 \mathrm{x}$ I002/I (GIo). Muranaka et al., (20I6) suggested that high grain yield variation could be due to greater differences between the genotypes and seasons. Nonetheless, yield levels above the mean alone is not sufficient for cultivar selection, but cultivars should be stable and perform much better than the check varieties (Kaya et al., 2006). In addition, Olayi- 
wola et al. (2015) and Olayiwola \& Arroyo (2013) reported the consequences of selecting high yielding but unstable genotypes in breeding programs to avoid commercial losses. The AMMI analysis of cowpea grain yield in 6 production environments showed that $62 \%$ of the sums of squares was explained by environment (E) and $8.5 \%$ and $29.4 \%$ were attributable to genotype $(\mathrm{G})$ and GEI, respectively. The large variations in environmental percentage for sum of squares reflect the significant differences in environments. The environment showed much variability in both additive main effects and interactions. Similar results were observed by Oliveira et al., (2013) and Jeberson et al., (2017) in their studies of passion fruit and bread wheat, respectively, in which most of the variation was attributed to environmental factors and G x E interaction. This was mainly due to the fact that biophysical attributes (biotic stresses, soils, temperatures and rainfall found at each location were highly variable) (Rukuni et al., 2006). In line with this, semi-arid regions of Kenya are known to have 2 agro-ecological zones that are diverse in physical properties such as soils, rainfall and temperatures (Jaetzold et al., 2006). Indeed in this study, there was relatively more rainfall in 2015SR than 20I6LR as shown in Table 2.

The study of Yan, (20II) elucidated that, the closer the IPCA scores are to zero the more stable the genotypes are across environments. Genotypes $\mathrm{G}_{5}, \mathrm{G}_{9}$ and $\mathrm{G}_{2}$ in AMMI analysis were broadly adapted and stable since they were located near the origin and hence insensitive to environmental interactions. Environments $\mathrm{E}_{2}$ and $\mathrm{E} 4$ revealed low interactions as they were near the point of origin compared to $\mathrm{E} 6$ and $\mathrm{E}_{5}$ which were positioned far away (Fig I). The position of genotype or environment provides some insight into GEI (Ceccarelli, 2012). Similarly, the GGE bi-plot results showed genotypes $\mathrm{G}_{5}$, G2, G9, G7 and $\mathrm{G}_{3}$ had very short vectors in relation to ATC axis indicating high stability. Similar results were also described by Krzysztof \& Marcin, (20I6). A genotype which has a shorter absolute length of projection in either of the two directions of the AEC ordinate (located closer to AEC abscissa), represents a smaller tendency of GEI which means it is the most stable genotype across different environments or vice versa (Ceccarelli, 20I2; Yan et al, 2007). Equally, genotype GII (IOOI) and G7 (IO02/1005/3) exhibited stable characteristics, though with lower mean grain yield. Oliviera \& Godoy (2006), suggested most stable genotypes do not always have the best yield.

The response of genotypes in different locations and Genotype by environment interaction (GEI) in relation to genotype effect suggested the possibility of mega environments with different genotypes (Oladosu et al., 20I7). The bi-plot detected 3 mega-environments:first Kbmi6LR (E3) and KbmI5SR (E5), second Kibr6LR (EI) and KitI5SR (E6), and third KibI5SR (E4) and Kitr6LR (E2). The environmental markers that have a short vector closer to the bi-plot origin are less interactive and it is considered an effective measure for selecting genotypes with average performance and adaptations (Murphy et al., 2009). In this case, environments KitI6LR (E2) and KitI5SR (E6) are less interactive with genotypes and therefore good environments for testing cowpea genotypes for adaptability and stability. According to Akter et al. (2014), the genotypes that cluster together tend to have a similar response in all environments while genotypes that are far apart differ in response to the environments. Therefore genotypes distant form origin is 
sensitive and have large interactions whereas those closer to the origin are not sensitive to environmental interactions. This method provides a more efficient exploration of the GEI to identify, select stable and adapted genotypes for specific environments and mega-environments (Safari et al., 20I4). The vertex genotypes in this study were $1005 / 1004 / \mathrm{I}$ (G6), I004/I00I/3 (G8), 1005/ I002/2/I/I (GI2), I00I (GII) and I005/1002/I (GIO). These genotypes were either best or poorest performers in some or all of the sites because they were located at the furthest distance from the origin of the bi-plot (Yan et al 2002; Yan et al, 2007).

\section{Farmer preferences for cowpea genotypes}

Participatory breeding is usually conducted to ensure adoption of newly developed crop cultivars and their production packages (Ceccareli et al., 2007). Formal cultivar selection and crop improvement programmes often focus on a few economically important traits such as yield and disease resistance (Alene \& Manyong, 2006). In this study, farmers generally preferred early maturing genotypes for drought escape, high yielding, pest and disease tolerant varieties with low shattering ability. During discussions with the farmers, the color of the grain and the grain size characteristics were mentioned for marketability. Tolerance to biotic and abiotic stresses, earliness, marketability, cooking characteristics, seed color and size and growth habit were important selection criterion (Assefa et al (2005), Humphries et al (2005) and Asfan et al. (2012). A lack of engagement between researchers and local farmers is a primary causes for low adoption of newly developed improved crop cultivars (Luna et al., 20II, Adesina and Baidu-Forson, I995).

\section{Conclusion and Recommendation}

The study established that cowpea performance for grain yield is greatly influenced by inherent genotypic factors, environment and their interaction effects, indicating the usefulness of GGE and AMMI analysis in distinguishing superior and stable genotypes. Genotype $\mathrm{G}_{5}, \mathrm{G}_{9}$ and $\mathrm{G}_{2}$ were regarded as ideal genotypes due to their high stability and high yield potential and can be recommended for release. The study also inferred that environments (E2) KitI6LR and (E6) KitI5SR are less interactive with genotypes and therefore, good environments for testing cowpea genotypes for adaptability and stability across eastern Kenya. Comparing farmers' preference scores with the calculated results for mean grain yield, it was concluded that farmers can predict strong performing varieties attributed to yield potential. Understanding farmer knowledge regarding varietal preference is important in the breeding of cowpea improvement for acceptance and eventual adoption. This study deduced that there are varied preferences and needs among the end users of the cowpea. Production of cowpea with consumer preferred attributes could enhance adoption and boost its cultivation in Kenya.

\section{Acknowledgements}

This study was funded by USAID- Food for the Future (FtF) project at KALRO. Our gratitude also go to KALRO for institutional support. We are grateful to our farmers who are 
the major stakeholders, the Ministry of agriculture team, field extension officers who assisted in the implementation of this study.

\section{References}

Adensina, A. A., \& Baidu-Forson, J. (I995). Farmers' perceptions and adoption of new agricultural technology: Evidence from analysis in Burkina Faso and Guinea, West Africa, Agricultural Economics, 13 , I-9

Alene, A.D. \& Mangong, V.M. (2006). Farmer to-farmer technology diffusion and yield variation among adopters the case of improved cowpea northern Nigeria. Agricultural Economics 35, 203-2II

Agbicodo, E. M., Fatokun C. C., Muranaka S., Visser R. G. F., \& Van der Linden, C.G. (2009). Breeding drought tolerant cowpea: constraints, accomplishments, and future prospects. Euphyticar67, $353-370$

Afyeman, K., Berchie, J.N., Ose-Bonsu, L., Tetteh, N.E. Fordjour, J.K. (20I4). Yield performance of improved cowpea (Vigna unguiculata L.) varieties in Ghana. 2(4), 44-52

Ajeibe, H.A., Ekeleme F. \& Chikoye D. (2010). Improved crop - livestock systems for enhanced food security and income generation in West Africa. Final project report: Gatsby improved crop livestock project. International institute of Tropical Agriculture (IITA), Ibadan, Nigeria, 5op

Akter, A., Hassen, J.M., Kulsum, U.M., Islam, M.R., Hossain, K. \& Rahman, M.M. (2014). AMMI biplot analysis for stability of grain yield in hybrid rice (Oryza sativa L.). J Rice Research, 2:I-4

Asrat, A., Assefa. T., Birhanu, A., Negash, K., Fisum, A., Fikadu, G., Rezene, Y., Chemeda, F., Mulegeta, A., Chemeda, D. (2009). Adaptation and Yield stability of small red beans elite line is Ethiopia. International Journal Plant Breeding, 2(2), $5 \mathrm{I}-63$

Asfan A., Cony, J., Almekinders, M., Blair, M. \& Strunk, P. (2012). Participatory approach in French bean breeding for drought tolerance in southern Ethiopia. Plant breeding I31:I25-I34

Assefa, T., Abebe, G., Finmsa, C., Tesso, B., \& Al-Tawoma, A. (2005). Participatory bean breeding with women and small scale farmers in Eastern Ethiopia. World Journal of Agriculture, 1(I), 28-35

Boukar, O., Massawe, F., Muranaka, S., Franco, J., Maziya, D., \& Fatukon, C. (20or) Evaluation of cowpea germplasm lines for minerals and protein content in grains. Plant Genetic Resources, 9(4), 515-522. Doi: Io.1017/SI4792621II000815

Cargnin, D., Souza, M.A., Carneiro, P.C.S. \& Sofiatti, V (2006). Genotypes and environment interaction and its implication in gain with wheat selection. Brazilian Agricultural Research, 4I, 987-993

Ceccarelli S., (2012). Plant Breeding With Farmers - A Technical Manual. ICARDA, pp xi + I26

Ceccarelli, S., Grando S., \& Baum, M. (2007). Participatory plant breeding in water limited environments. Experimental Agriculture Journal, 43, 4II - 436.

Chepkoech, W., Mungai, N.W., Stober, S., Bett, H., \& Lotze-Campen, H, (2018). Farmers' perceptive:-. Impact of climate change on African indigenous vegetable production in Kenya", International Journal of Climate Change Strategies and Management, Io(4), 55I -579. Doi.org/Io.IIo8/ IJCCM-07-2017-0I6

Cruz, C.D., Begazzi, A.J., \& Carneiro P.C.S. (2012). Biometrics models applied to genetics improvement. UFV, Vicosa,

Ddamulira, G., Obuo P., Santos, C. \& Alanyo, M. (2015). Grain yield and protein content of Brazilian cowpea genotypes under diverse Ugandan environments. American Journal of Plant Science, 6, 20742084

FAO (20I4). Appropriate Seed Varieties for Small-scale Farmers: Key Practices for DRR Implementers.

FAOSTAT (2018). Food and Agricultural Organization of the United Nations. Statistical database. http://faostat.org 
Farshadfar E. R, Mahmodi, N. and Yaghotipor, A. (20II). AMMI stability and simultaneous estimation of yield and yield stability in bread wheat (Triticum asetivum L). Australian Journal of Crop Science 5(I3): $1837-1844$

Ferreira, D.F., Demetrio C.G.B., Manly B.F.I., Machado, A.A. \& Vencovsky, R. (2006). Statistical model in agriculture: Biometrical methods for evaluating phenotypes stability in plant breeding. Cerne Lavras, I2(4); 373-388

Funga, A., Tadessese, M., Mohamed, R., Bishaw, Z., Rao, G, Siambi, M., Monyo, E., Gaur, P. \& Ojiewo, O. (2017). Genotype by environment interaction on yield stability of desi type chickpea (Cicer arietinum) at major chickpea producing areas of Ethiopia. Australian Journal of Crop Science, II(02), 2I2-2I9. Doi: 10.2I475/ajsc.I7.II.02.p297

GENSTAT $14^{\text {th }}$ edition, (2012). Statistical Software. University of Reading, UK. www.genstat.co.uk

Humphries, S., Gallardo, O., Jimenez, J., \& Sierra, F. (2005). Linking farmers to the formal research sector lessons from a participatory bean breeding program in Honduras. Network Paper Agricultural Research and Extension network 142, 4 -I4

Hutchinson, M.J., Muniu, F.K., Ambuko, J. Mwalangalu, M., Mwang'ombe, A. W., Okello, J., \& Olubayam, F. (2016). Effect of cattle manure and calcium ammonium nitrogen on growth and leaf yield of local cowpea accessions in coastal Kenya. Journal of Plant and Soil Science, I2(3), I-I2

IITA, (2009). Cowpea project for Africa Research and Development. International Institute of Tropical Agriculture. Available at: http//www.iita.org/crop/cowpea.

Idrissi, O., Sahri, A., Houasli, C. \& Nsarellah N. (2019). Breeding progress. Adaptation and stability for grain yield in Moroccan Lentil improved varieties. Crop Science, 59, I-I2. Doi:I0.2I35/ cropsci2018.07.043I

Jaetzold, R., Schmidt, H., Hornetz, B., \& Shisanya C. (2006). Farm Management Handbook of Kenya Vol. II: Natural Conditions and Farm Management Information 2nd Edition Part C, East Kenya, Subpart Cr Eastern Province, Kenya, 573 p

Jeberson, M.S., Kant, L., Kishore N., Rana, V., Walia, D.P., \& Singh, D. (2017). AMMI and GGE Bi-plot analysis of yield stability and adaptability of Elite genotypes of bread wheat (Triticula aestivum L) for Northern Hill zone of India. International Journal of Bio-Resource and Stress Management, 8(5):635-64I. DOI.ORG/I0.239Io/IJBSM/2017.8.5.1838

Kaya, Y., Acura, M., \& Tanner, S. (2006). GGE bi-plot analysis of multi-environment yield and stability in bread wheat. Turkish Journal of Agriculture and Forestry, 30(5), 325 -337

Kariuki, J. (2015). Food Security \& Crop Seed in Kenya, Challenging Trends We cannot afford to ignore. Policy brief

Kanouni, H., Farayedi, Y., Saeid, A., \& Sabaghpour, S.H. (2015). Stability analyses for seed yield of chick pea (Cicer arietinum L.) genotypes in the Western cold zone of Iran. Journal of Agricultural science, $7,219-230$

Krzysztof, U. \& Marcin, K. (2016) Application of GGE bi-plot graphs in multi-environments trials in selection of forest trees. Folia forestalia Polanica, series -Forestry 58(4):228-239 DOI: 10.1515/ ffp-2016-0026

Kumar, A., Verulkar S.B., Mandal, N.P., Varia M., Shukla, V,D, Dwivedi, J,L.,\& Robin, S. (2012). High yielding, drought tolerant, stable rice genotypes for the shallow rainfed lowland drought-prone ecosystem. Field crops research 133, 37-47

Luna, F.B., Hinojosa, M., Ayala, O., Castillo, F. \& Mejia, J. (2012). Prospects for the development of the corn seed industry in Mexico. Fitotechnia Mexicana Magazine, 2012, 35, I -7

Mehari, M., Tesfay, M., Yirga, H., Mesele, A., Abebe, T., Workineh, A., \& Amare, B. (2015). GGE-biplot analysis of genotype-by-environment interaction and grain yield stability of bread wheat genotypes in South Tigray, Ethiopia. Communication in Biometry and Crop Science, 10, 17- 26

Miriti, J.M, Kironchi, G., Esilaba, A.O., Heng, L.K., Gachene, C.K.K., \& Mwangi D.M. (2012). Yield and water use efficiencies of maize and cowpea as affected by tillage and cropping systems in semiarid Eastern Kenya. Agricultural Water Management, 115, I48-155 
Muranaka, S., Shonoi, M., Myoda, T., Takauchi, J., Franco J., Nakazawa Y., Boukar, O., \& Takagi H. (2016). Genetic diversity of physical nutritional and functional properties of cowpea grain and relationships among traits. Plant genetic resources: Characterization and utilizations I4(I): $67-76$

Murphy, S.E., Lee, E.A., Woodrow I., Seguin P., Kumar J., Rajcan L., \& Ablett G.R. (2009). Genotype x Environment interaction and stability for isoflavone content in soybean. Crop Science 39:1313I32I

Olayiwola, M.O., Soreni, P.A.S., \& Okeleye, K.A. (2015). Evaluation of some cowpea (Vigna unguiculata L. [Walp]) genotypes for stability of performance. Current Research in Agricultural Sciences, 2 (I), 22-30

Olayiwola, M.O., \& Ariyo, J.O. (2013). Relative discriminatory ability of GGE bi-plot and YSi in the analysis of genotype by environment interaction in Okra (Abelmoschus esculentus). International Journal of Plant Breeding and Genetics, 7, I46-158

Oliveira, E.J., Freitas, J.P.X., \& Jesus, O.N. (2013).AMMI analysis of the adaptability and yield stability of yellow passion fruit. Scientia Agricola 7I(2):I39 -I45

Oliviera, E.J., \& Godoy, I.J. (2006). Pod yield stability analysis of runner peanut lines using AMMI. Crop Breeding and Applied Biotechnology 6: $311-317$

Oladosu, Y, Rafii, M.Y., Abudulla, N., Magaji, U., Miah, G., Hussin, G., \& Ramli A. (2017). Genotype x Environment interactions and stability analysis of yield and yield components of established and mutant rice genotypes tested in multiple locations in Malaysia, Acta Agriculturae Scandinavica, Section B- Soil and Plant Science 67(7), 590-606. Doi:10.1080/09064710.2017.1321138

Paris, T.R., Manzanilla, D., Tatlonghari, G., Labios, R., Cueno, A. \& Villanueva, D (20II). Guide to participatory varietal selection for submergence- tolerant rice. Los Banos: (Phillipines) International Rice Research Institute. IIIp

Quarrie, S., Quarrie, S.P., Radosevic, R., Rancic D., Kaminska, A., Barnes J.D, Leveringtone J. (2006). Dissecting a wheat QTL for yield present in a range of environments from the QTL to candidate genes. Journal of Experimental Botany, 57(II), 2627-2637

Raboanatahiry, N., Chao, H., Dalin, H., Pu, S., Yan, W., Tu, L. Wang, B., Li, M. (2018). QTL Alignment for seed yield and yield related traits in Brassica napus. Plant Science Journal. Doi.org/10.3389/ fpls.2018.01127

Rashidi, M., Fashadfar, E. \& Jowkar., M.M. (2013). AMMI analysis of phenotypic stability in chickpea genotypes over stress and non-stress environments. International Journal of Agricultural Crop science, $5,253-260$

Rukuni, M., Eicher, C.K., \& Blackie,, J. (Eds). (2006). Zimbabwe's Agricultural Revolution, Revisited, University Of Zimbabwe Publications, Harare.

Safari, S., Dolatabad, A.E., Choukanc, R., Hervan, E.M., \& Dehghani, H. (2014). Bi-plot analysis for multi-environment trials of maize (Zea mays L.) hybrids in Iran. Crop \& Pasture Science, 6I, 700-707.

Saidou, A.K., Ajeigbe, H. K. \& Singh, B.B. (20II). Participatory evaluation of improved cowpea lines and cropping systems for enhancing food security and income generation in Niger republic. Journal of Agricultural and Environmental Science, II: 55 -6I

Salifou, M., Tignegre, B.L.S., Tongoona, P., Offei, S., Ofori, K. \& Danquah, E. (2017). Farmers' preffered Traits and Perceptions of Cowpea production and Constraints in Niger. Journal of Agriculture and Food Technology, 7(6) I-II

Sani, A., Abubakar, B.Z. Yakubu, D.H., Atala, T.K., \& Abubakar, L. (2014). Social- economic factors influencing adoption of dual purpose cowpea production technologies in Bichi local government. Area of Kano State, Nigeria. Asia Journal of Agricultural Extension Economics and Sociology, 258-273

Santos, A., Ceccon, G., Teodoro, P.E., Correa M.A., Alvarez, F. C. R., Silva, F.J., Alves B.V. (2016). Adaptability and stability of erect cowpea genotypes via REML/BLUP and GGE Bi-plot. Campinas, 75(3), 299-306. 
Singh, C.M., Mishra, S.B., Pandey, A., Arya M. (2014). Eberhart - Russell and AMMI approaches of genotype by environment interaction (GEI) for yield and yield component traits in Vigna radiata L. Wilezek. International Journal of Agriculture \& Biotechnology, 7(2), 277-292. Doi:10.5958/2230732 X2014.00245.9

Sousa, B.M., Silva, D.J.K., Rocha, M.M., Júnior M.N.J., \& Lima L.R.L. (2018). Genotype by environment interaction in cowpea lines using GGE bi-plot method. Doi: 10.1590/1983-21252018v3InIo8rc

Tijjani, A. R. Nabinta, R. T. \& Muntaka, M. (2015) Adoption of innovative cowpea production practices in a rural area of Katsina State, Nigeria. Journal of Agricultural and Crop Research. 3(4), 53-58.

Tilahuni, G., Mekbi, F., Fikre, A., \& Eshete, M. (2015). Genotype x environment interaction and stability analysis for yield related traits of Kabuli-type chickpea (Cicer arientinum L.) in Ethiopia. African journal of Biotechnology, I4(I8), I564-I575. Doi; I0.5897/AJB2014.I4320.

Thanki, H.P., Swargaonkar, S.L. \& Hudge, B.V. (2010). Genotype x environment interaction for biometrical traits in pigeonpea (Cajanus cajan L. Millsp.) under varying spacings. Electronic Journal of Plant Breeding, I(4), 925-928

USAID, United states Agency for international Development. 2010. Staple foods Chain Analysis, Country report-Kenya, pp I53

Vita, P, D., Mastrangela, A.M., Matteua, L., Mazzucotellib, E., Virzi, N., Palumboc, M., Stortod, M.L., Rizzab, F., Cattivelli L. (2010). Genetic improvement effects on yield stability in durum in Italy. Field Crop Research II9, 68-77

Yan, W., Kang, M.S., Ma, B., Wood, S. \& Cornelius P.L. (2007). GGE vs AMMI Analysis of Genotype by- Environment data. Crop Science 47: 643:655

Yan, W., \& Hunt, L.A. (2002). Bi-plot analysis of multi-environment trial data, in M.S. Kanga (ed) Quantitative Genetics, Genomics and plant breeding CAB international, Wallingford

Yan, W., Hunt, L.A., Sheng, Q., \& Szlavnics, Z. (2000). Cultivar evaluation and mega environment investigation based on the GGE bi-plot. Crop science, 40(3), 597-605

Yan W., Pageau, J., Fregeau-reid \& Durand, J. (20II). Assessing the representatives and repeatability of test locations for genotype evaluation. Crop Science, 5(4), I603-I6ro

Yan W., \& Rajcan, I. (2002). Bi-plot analysis of tests sites and trait relations of Soybean in Ontario. Crop Science, 42 , II-20 